\title{
The change in the specific leaf area of maize grown under Mediterranean conditions
}

\author{
NG Danalatos ${ }^{1 \star}$, CS Kosmas ${ }^{1}$, PM Driessen ${ }^{2}, \mathrm{~N}$ Yassoglou 1 \\ ${ }^{1}$ Agricultural University of Athens, Laboratory of Soils and Agricultural Chemistry, lera Odos, 75, Botanikos 11855, Athens, Greece; \\ ${ }^{2}$ Agricultural University of Wageningen, Department of Soil Science and Geology, Duivendaal, 10, \\ 6700 AA Wageningen, The Netherlands
}

(Received 5 March 1994; accepted 3 October 1994)

\begin{abstract}
Summary - The change in the specific leaf area (ie the leaf area per dry matter weight unit) of 2 single maize hybrids was studied in 4 field experiments carried out in central and northern Greece in 1987 and 1988. It was found that the overall specific leaf area of maize takes an initial value much lower than the values suggested for central European conditions and decreases as a function of the development stage of the crop, independent of location, cultivar, plant density (within the normal range), soil conditions, irrigation management and crop growth. A methodology for calculating the development stage based on the accumulated thermal units method is also discussed. Further, the validity of the produced empirical relation between specific leaf area and development stage was tested for 13 more maize plantings grown in western Greece in 1991. A fairly good agreement with the measured values especially before flowering (end of leaf growth) was found, suggesting that the empirical relation may be used in modern crop growth models simulating maize growth under Greek and more generally Mediterranean conditions.
\end{abstract}

specific leaf area / maize / development stage / accumulated thermal units method

Résumé - Modification de la surface foliaire spécifique du maïs dans les conditions culturales méditerranéennes. La modification de la surface foliaire spécifique (surface foliaire par unité de poids de matière sèche) de 2 hybrides de maïs a été étudiée, dans 4 expérimentations au champ, dans le centre et le nord de la Grèce en 1987 et 1988. II a été constaté que la surface foliaire spécifique totale a une valeur initiale assez faible par rapport aux valeurs qui sont proposées pour les conditions d'Europe centrale. Elle diminue avec le stade de développement de la culture indépendamment du lieu, de la variété, de la densité de plantation (dans la gamme couramment utilisée), des conditions du sol, de la gestion de l'irrigation et de la croissance des plantes. Une méthode de calcul du stade de développement, basée sur la méthode des sommes de températures, a été aussi discutée. En outre, la validité de la relation empirique obtenue entre la surface foliaire spécifique et le stade du développement a été testée sur 13 cultures de maïs dans l'ouest de la Grèce en 1991. Une bonne concordance a été constatée, particulièrement pour les valeurs obtenues avant la floraison (fin du développement des feuilles), montrant que cette relation empirique pourrait être utilisée dans des modèles modernes de simulation du développement des plantes et spécialement du développement du maïs dans les conditions culturales grecques et plus généralement méditerranéennes.

surface foliaire spécifique / maïs / stade de développement / méthode des sommes de températures

${ }^{*}$ Correspondence and reprints 


\section{INTRODUCTION}

Leaf area expansion is of great importance for light interception and for photosynthesis; it varies with the quantity of assimilates allocated to the production of leaves and the ratio of the leaf area produced per unit of leaf dry matter. The specific leaf area (SLA, normally expressed in $\mathrm{m}^{2} \mathrm{~kg}^{-1}$ ) is a morphological plant characteristic; for a given species, its value changes as a function of environmental conditions and age of the crop.

Many authors have demonstrated that an inverse proportionality exists between SLA and light intensity (Blackman et al, 1955; Cooper, 1966; Butt, 1968; Pears and Lee, 1969; Gmeling Meyling, 1973). As a general symptom, at high light intensities and photosynthetic rates, the thickness of the leaves increases and therefore SLA decreases, because carbon fixation exceeds translocation. Chatterton et al (1972) consider the SLA as a measure of the photosynthate production-translocation balance and that its change may reflect productivity potential; the inability to rapidly translocate and utilize the products of photosynthesis may reduce the potential growth of many plants. The same authors found diurnal fluctuations in experiments with maize and alfalfa, suggesting the use of diurnal change of SLA as a selecting criteria for identifying genotypes for efficient translocation. The fact that SLA is also affected by temperature at high levels of light was shown by Blackman et al (1955) and Gmeling Meyling (1973): maize leaves become thicker at lower temperatures but are not much longer and this goes with a decrease in fresh and dry SLA (Brower et al, 1973). This phenomenon has been attributed to a lower conversion rate of primary photosynthates to structural leaf material, with accumulation of soluble carbohydrates in the leaves. Additionally, the rate of the leaf area expansion may be reduced under low temperatures (Grobbelaar, 1963; Kleinendorst and Brower, 1970).

In the last few years, SLA has received great attention, particularly after the development of models that accurately simulate the production of assimilates and their distribution to the various plant organs (SUCROS, Spitters et al, 1988; WOFOST, Rappoldt, 1986; Wolf et al, 1986). In such models, SLA is input as a rate variable (Van Heemst, 1988). As the existing data on SLA are still of an exploratory nature, the scope of the present work is to further study the change in the specific leaf area of maize grown under conditions of the long, warm and sunny summers that are characteristic of Greece and more generally the Mediterranean region.

\section{MATERIALS AND METHODS}

\section{Field experiments}

The leaf area characteristics and the change in SLA of maize were studied in 4 field experiments in Larissa (350 km north of Athens) and in Thessaloniki $(510 \mathrm{~km}$ north of Athens), involving the 2 most commonly used cultivars in Greece. The Larissa and Thessaloniki plains are the largest lowland formations in Greece where high input agriculture is practised. Table I summarizes the main characteristics of the field experiments.

\section{Experiment 1}

This concerned the growth of the maize (single-cross) hybrid Aris on a flat, light clay soil in Larissa (central Greece) in 1987 (table I). A randomized block design was used with 3 replicate plots of $6 \times 6 \mathrm{~m}=36 \mathrm{~m}^{2}$. The site received adequate fertilization and irrigation for maximum growth (table I). The dates of $50 \%$ emergence, flowering (tasselling), silking and maturity were recorded. The occurrence of a black layer on $50 \%$ of the kernels was used as an indication that the crop had fully matured (Rench and Shaw, 1971). The crop was harvested on the following dates: 10/6, 25/6, 15/7, $30 / 7,20 / 8,3 / 9$ and $18 / 9 / 1987$. The sampling was finalized within $2 \mathrm{~h}$ after sunrise. For the first 2 harvests, 2 strips of $2 \mathrm{~m}$ were taken from each replicate. Later, the size of the harvested strips was reduced, with sample weights of no more than $300-400 \mathrm{~g}$ per replicate and per treatment. Leaf blades, leaf sheaths, stalks and cobs + husks were harvested separately. The surface area of 20 leaf blades from each replicate was accurately measured by planometer and correlated with the leaf length and width (see Results and Discussion). The total leaf area of the crop was then calculated from the measured lengths and widths of all leaves in the sample. All the samples were dried at $70^{\circ} \mathrm{C}$ until constant weight. Combining the leaf area and dry leat weight produced the instantaneous average specific leaf area $\left(\mathrm{m}^{2}\right.$ leaf $/ \mathrm{kg}$ dry leaf mass). The daily maximum and minimum air temperatures (at the nearby Larissa Station) were supplied by the National Meteorological Service (fig 1).

\section{Experiment 2}

This was conducted on a flat, loamy sandy soil in Thessaloniki (northern Greece) in 1987. The site received fertilization and irrigation for optimum growth (table I). The same design as in Experiment 1 was used with 3 replicate plots of $12 \mathrm{~m}^{2}$ each. The crop was harvested on the following dates: $28 / 5,19 / 6,17 / 7$, $31 / 7,21 / 8,4 / 9$ and $21 / 9 / 1987$. The daily maximum and minimum temperatures were recorded on-site. 
Table I. Main characteristics of the 4 field experiments in Larissa and Thessaloniki in 1987 and 1988.

Characteristic

1

2

Larissa

1987

Year

Cultivar

Sowing date

Plant density

(plants/ha)

Fertilization

Irrigation

(mm water)

480

+ groundwater

kg N/ha

$80 \mathrm{~kg} \mathrm{P} / \mathrm{ha}$

$120 \mathrm{~kg} \mathrm{~K} / \mathrm{ha}$

520

Irrigation method

Travelling gun

Furrows

\section{Experiment}

3

4

5

$\begin{array}{llll}\text { Thessaloniki } & \text { Larissa } & \text { Thessaloniki } & \text { Agrinio } \\ 1987 & 1988 & 1988 & 1991 \\ \text { P3165-Dona } & \text { Aris } & \text { P3165-Dona } & \text { P3165, Aris } \\ 23 / 4 / 87 & 3 / 5 / 88 & 28 / 4 / 88 & 7 / 4-25 / 5 / 1991 \\ 80000 & 70000 & 80000 & 70000-85000 \\ & & & \\ 500 \mathrm{~kg} \mathrm{~N} / \mathrm{ha} & 445 \mathrm{~kg} \mathrm{~N} / \mathrm{ha} & 360 \mathrm{~kg} \mathrm{~N} / \mathrm{ha} & 350-450 \mathrm{~kg} \mathrm{~N} / \mathrm{ha} \\ 80 \mathrm{~kg} \mathrm{P} / \mathrm{ha} & 90 \mathrm{~kg} \mathrm{P} / \mathrm{ha} & 80 \mathrm{~kg} \mathrm{P} / \mathrm{ha} & 50-90 \mathrm{~kg} \mathrm{P/ha} \\ 120 \mathrm{~kg} \mathrm{~K} / \mathrm{ha} & & 120 \mathrm{~kg} \mathrm{~K} / \mathrm{ha} & - \\ & & & \\ 520 & 781(\operatorname{tr} \mathrm{K}) & 140 & 7-8 \text { applications } \\ & 134(\operatorname{tr} \mathrm{A}) & + \text { groundwater } & \text { with } 50-70 \mathrm{~mm} \\ & 1280(\operatorname{tr} \mathrm{Y}) & & \text { per application } \\ & 915(\operatorname{tr} \mathrm{PY}) & & \end{array}$

Drip

Furrows

Furrows

$\mathrm{tr}=$ treatment

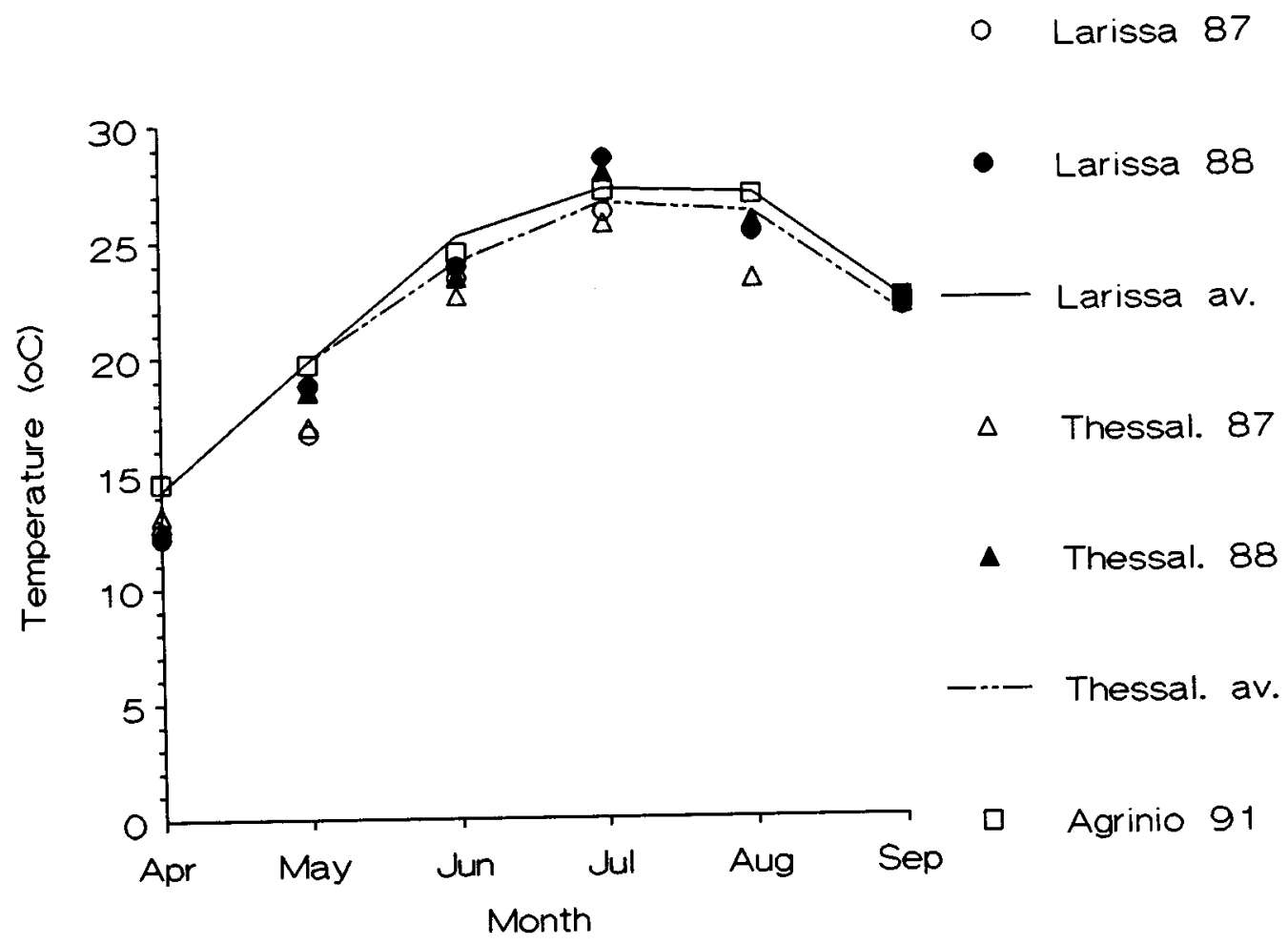

Fig 1. Monthly air temperatures in Larissa and Thessaloniki in 1987, 1988 and an average year and in Agrinio 1991 (data source: National Meteorological Service). 


\section{Experiment 3}

This was established on the Larissa clay soil in 1988. The site received optimum fertilization (table I). Drip irrigation was applied at a constant (low) discharge of $2.5 \mathrm{~mm} / \mathrm{h}$. A randomized block design was used with 4 treatments and 3 replicates. The treatments were:

Treatment $K$ : normal irrigation; a net total of $386 \mathrm{~mm}$ irrigation water was applied from sowing to silking, and $395 \mathrm{~mm}$ from silking to maturity.

Treatment A: dry throughout; only $134 \mathrm{~mm}$ of water was applied for establishment.

Treatment $Y$ : the 'wet treatment'; with a total effective irrigation water input of $860 \mathrm{~mm}$ from sowing to silking and $420 \mathrm{~mm}$ from silking to maturity to ensure optimal production.

Treatment PY: same as $Y$ until silking, dry thereafter; only $55 \mathrm{~mm}$ of water was applied between silking to maturity.

The crop was harvested 6 times, viz on the following dates: 2/6, 23/6, 11/7, 28/7, 10/8 and 23/8/1988. The sampling procedure was as in Experiment 1; the sampled matter was divided by plant organ, and leaf area measurements were done as in the above experiments.

\section{Experiment 4}

This was laid out on the Thessaloniki loamy sand in 1988. The site received adequate fertilization for optimum growth (table 1). Due to lack of water in the area, only 2 irrigations (furrow) were given, viz on June 20 and July 6 , with $70 \mathrm{~mm}$ effective water depth per application. The crop was harvested on $12 / 7$ and $17 / 8$. The daily maximum and minimum temperatures were recorded on site. The heat requirements for emergence, flowering and maturing of maize were calculated by interpreting records on emergence, flowering and maturity of an additional number of plantings of $\mathrm{cV}$ Aris and Pioneer 3165-Dona in neighbouring fields in 1987 and 1988.

\section{Experiment 5}

This concerns the measurements of maize development and leaf growth in Agrinio plain (western Greece) during the growing period of 1991. In this plain, which is characterized by recent alluvial, very deep, mediumto-fine-textured, calcareous soils, (irrigated) maize is a widely cultivated crop.

The dates of emergence, flowering and maturity of 13 maize plantings with different cultivars, sowing dates and sowing densities were recorded (table I). The crops were additionally sampled for leaf dry mass on the dates $5 / 6,18 / 6,3 / 7,18 / 7,30,7$ and $13 / 8 / 1991$. Before sampling, the leaf area index (LAI) was measured on site using a plant canopy analyzer (LICORLAI 2000). The specific leaf area was calculated using the measured LAl-value and the dry leaf weight measured for the 4 plants surrounding the spot where LAI was measured, for the given plant density. Three replicates for each of the 13 plantings were used. The determined SLA was plotted versus the development stage of the crop. The latter was calculated using daily temperature records as explained below.

\section{Development of the crop}

The heat requirements from planting or emergence to flowering are normally established by summation of daily effective temperatures, calculated by subtracting a base (or threshold) temperature from the daily mean. The superiority of the thermal time method over the calendar-day method has been shown in numerous works (Brown, 1969; Blacklow, 1972; Arnold, 1975; Coelho, 1978; Tollenaar et al, 1979; Derieux and Bonhomme, 1982 ), but there is no universal agreement on the best method to compute threshold and ceiling temperatures.

The emergence, flowering (tasselling) and maturity of a number of maize plantings in 1987 and 1988 are summarized in table II. The best method to calculate the accumulated heat units would be one that minimizes their coefficient of variation (CV) obtained

Table II. Emergence (E), flowering ( $F$ ) and maturity (M) dates of some maize (Aris and Pioneer) plantings in 1987 and 1988.

$\begin{array}{llllllll}\text { Cultivar } & \text { Location } & \begin{array}{l}\text { Emergence } \\ \text { date }\end{array} & \begin{array}{l}\text { Flowering } \\ \text { date }\end{array} & \begin{array}{l}\text { Maturity } \\ \text { date }\end{array} & \begin{array}{l}E-F \\ (d)\end{array} & \begin{array}{l}F-M \\ (d)\end{array} & \begin{array}{l}E-M \\ (d)\end{array} \\ & & & & & & & \\ \text { Aris } & \text { Larissa } & 22 / 4 / 87 & 5 / 7 / 87 & 30 / 8 / 87 & 74 & 56 & 130 \\ \text { Aris } & \text { Larissa } & 20 / 5 / 87 & 15 / 7 / 87 & 10 / 9 / 87 & 56 & 57 & 113 \\ \text { Aris } & \text { Larissa } & 10 / 5 / 88 & 4 / 7 / 88 & 26 / 8 / 88 & 55 & 53 & 108 \\ \text { Aris } & \text { Thessaloniki } & 8 / 5 / 88 & 5 / 7 / 88 & \text { na } & 54 & \text { na } & \\ \text { P3165 } & \text { Thessaloniki } & 4 / 5 / 87 & 19 / 7 / 87 & 18 / 9 / 87 & 76 & 61 & 137 \\ \text { P3165 } & \text { Thessaloniki } & 9 / 5 / 88 & 10 / 7 / 88 & 3 / 9 / 88 & 62 & 54 & 116\end{array}$


between different trials (years $x$ locations) (Derieux and Bonhomme, 1982). For both periods from emergence to flowering and from flowering to maturity of 4 Aris plantings (table II), the smallest $\mathrm{CV}$ was found by summing the daily temperatures above a threshold value according to:

$$
T_{\text {SUM }}=\sum\left[0.5\left(T_{\max }+T_{\min }\right)-T h\right]
$$

where

$T_{\text {SUM }}$ is the accumulated heat units $\left({ }^{\circ} \mathrm{C} \cdot \mathrm{d}\right)$,

$T_{\max }$ is the maximum daily temperature $\left({ }^{\circ} \mathrm{C}\right)$,

$T_{\min }$ is the minimum daily temperature $\left({ }^{\circ} \mathrm{C}\right)$,

$T h$ is the threshold temperature equal to $10.5^{\circ} \mathrm{C}$.

The present approach based on the values established for the heat requirements during emergence to flowering and flowering to maturity (Tsumpre and $T_{\text {sumpost, respectively) assumes that the rate of }}$ development of the maize cultivars studied is constant during these periods. Assuming a linear development during these periods, the development stage of the crop (DVS) at any time can be estimated as follows:

$$
\text { If } T \mathrm{a} \geq \mathrm{Th} \quad \text { then } T_{\mathrm{ACT}}=T_{\mathrm{ACT}}(\text { old })+\left(\mathrm{T}_{\mathrm{a}}-\mathrm{Th}\right)
$$

If $T_{\mathrm{ACT}} / T_{\text {SUMpre }}<1$

$$
\text { then DVS }=0.5^{*}\left(T_{\mathrm{ACT}} / T_{\mathrm{SUM}} \mathrm{pre}\right)
$$

If $T_{\mathrm{ACT}} / \mathrm{T}_{\text {Sumpre }} \geq 1$

then DVS $=0.5+0.5 *\left[\left(T_{\mathrm{ACT}}-T_{\text {SUM }}\right.\right.$ pre $\left.) / T_{\text {SUMpost }}\right][4]$

where

$\mathrm{T}_{\mathrm{a}}=$ mean daily air temperature $=\left(T_{\max }+T_{\min }\right) / 2\left({ }^{\circ} \mathrm{C}\right)$,

$T h=$ threshold temperature $\left(10.5^{\circ} \mathrm{C}\right)$,

$\mathrm{T}_{\mathrm{ACT}}=$ total accumulated heat sum above $\operatorname{Th}\left({ }^{\circ} \mathrm{C} \cdot \mathrm{d}\right)$.

In the present approach, DVS $=0.5$ at flowering and DVS = 1 at maturity. The DVS approach is as easy as the thermal time approach and has the additional advantage of using the same scale $(0-1)$ for all crops/cultivars, for which the sum of degree-days may considerably vary. It should be stressed that the sum of temperature for a given genotype has to be known in order to use the DVS-based approach. This sum is constant and characterizes a given genotype. If temperature sum and threshold temperature are not known, these characteristics can be found by performing at least 2 experiments under different temperature conditions.

\section{RESULTS AND DISCUSSION}

\section{Heat requirements of the studied cultivars}

Applying equation [1] suggested that the cv Aris needs 660 degree-days for flowering ( $T_{\text {Sumpre }}=$ $660, \mathrm{CV}=1.1 \%$ ); the heat requirement of the cul- tivar Pioneer 3165-Dona is $T_{\text {sumpre }}=780$.

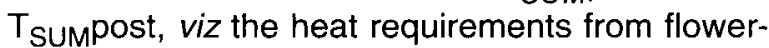
ing to maturity, is 850 degree-days for both cvs Aris (CV $=1.9 \%$ ) and Pioneer 3165 . The value of $10.5^{\circ} \mathrm{C}$ is almost identical to that $\left(10^{\circ} \mathrm{C}\right)$ found in many classical studies (Gilmore and Rogers, 1958; Arnold, 1975) and adopted in many recent publications (Van Heemst, 1986, 1988; Driessen and Konijn, 1992). For some European sites, somewhat smaller threshold temperature values were suggested (Derieux and Bonhomme, 1982), which might be attributed to the adaptation of maize to the lower temperatures prevailing in those areas.

The superiority in predicting flowering and maturity times based on the heat units method rather than on the calendar-day method is apparent from figure 2, where the accumulated heat units are plotted for 4 plantings of $\mathrm{cv}$ Aris in Larissa and Thessaloniki, in 1987 and 1988. The accumulated heat units are calculated for each planting starting from the actual day of emergence; the days of emergence $(E)$, flowering (tasselling) $(F)$ and maturity $(M)$ are indicated on the graphs.

\section{Leaf characteristics - specific leaf area}

As mentioned above (see Materials and Methods), a good correlation between leaf length/width and the leaf area allowed us to estimate the latter from the measured lengths and widths of all leaves in the sample. Actually, the leaf surface area $\left(E\right.$, in $\left.\mathrm{cm}^{2}\right)$ could be related to the product of length $(L$, in $\mathrm{cm})$ times width $(W$, in $\mathrm{cm}$ ) of the leaf blades according to the following linear relations for cv Aris and cv Pioneer 3165, respectively:

$$
\begin{aligned}
& E=0.7795(\mathrm{LW})-4.168 \quad(R=0.996, n=221) \\
& E=0.7370(\mathrm{LW})-5.89 \quad(R=0.994, n=100)
\end{aligned}
$$

The change of the LAl with the DVS of Aris and Pioneer cultivars is presented in figure 3 . It can be seen that the LAl of cv Aris ranges from 4.2 to 5.2 at maximum leaf growth and is less than the LAl of the Pioneer which exceeds 7 . It can also be noted that the LAI is maximum at tasselling or later (DVS $=0.5-0.6$ ). The amount of assimilates partitioning to the leaves was found to be nil at DVS $\geq 0.65$ (Danalatos, 1993). Later, LAI decreases drastically due to dying off of senescent leaves, especially under dry conditions (treatment PY; fig 3). 


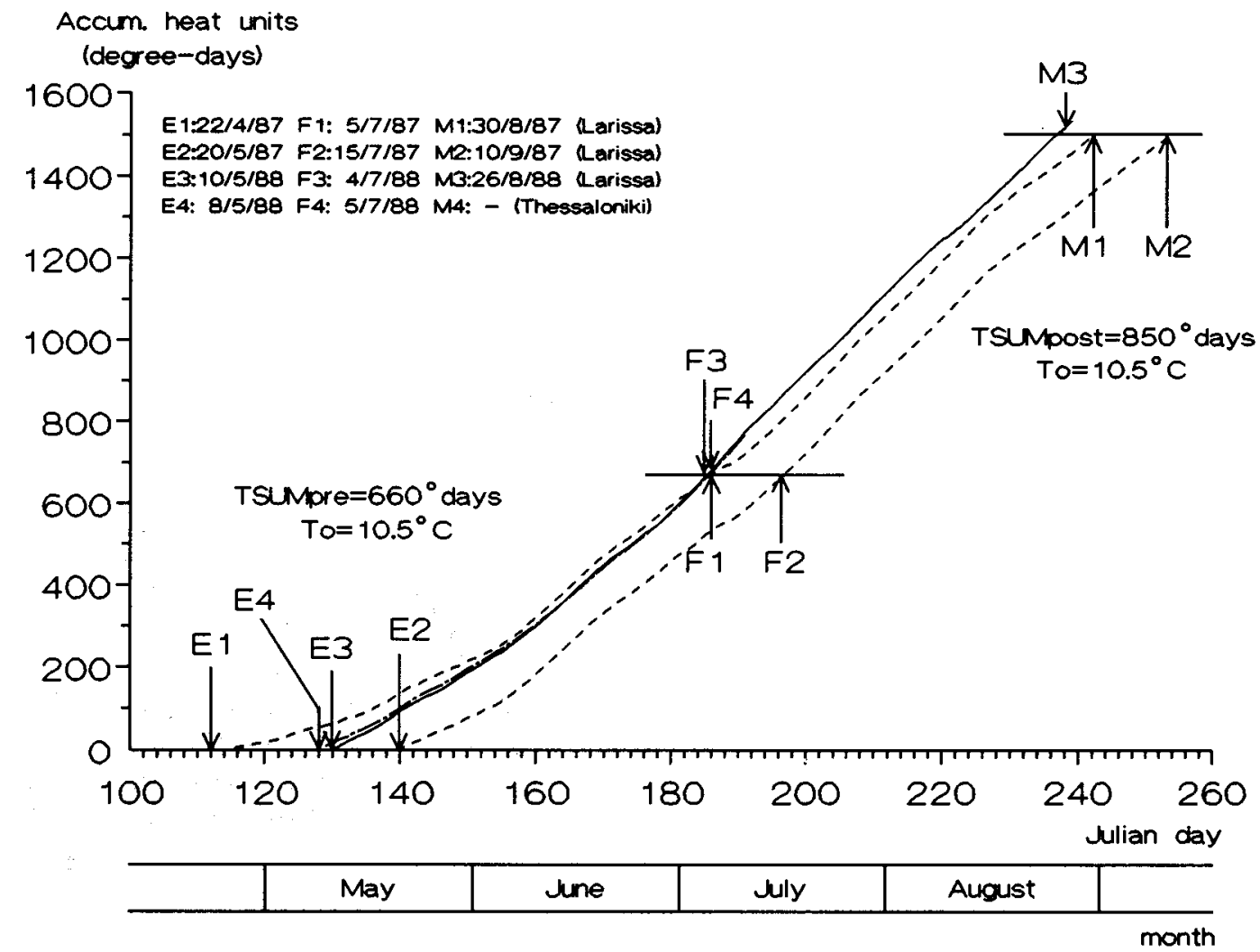

Fig 2. Accumulated heat units during the growing season of 4 plantings of maize cv Aris in Larissa in 1987 and 1988 , and in Thessaloniki in 1988 ( $E$ = emergence, $F=$ tasselling, $M=$ maturity; $T_{\text {SUM }}$ pre, $T_{\text {SUM }}$ post $=$ accumulated heat units required from emergence to flowering and from flowering to maturity, respectively).
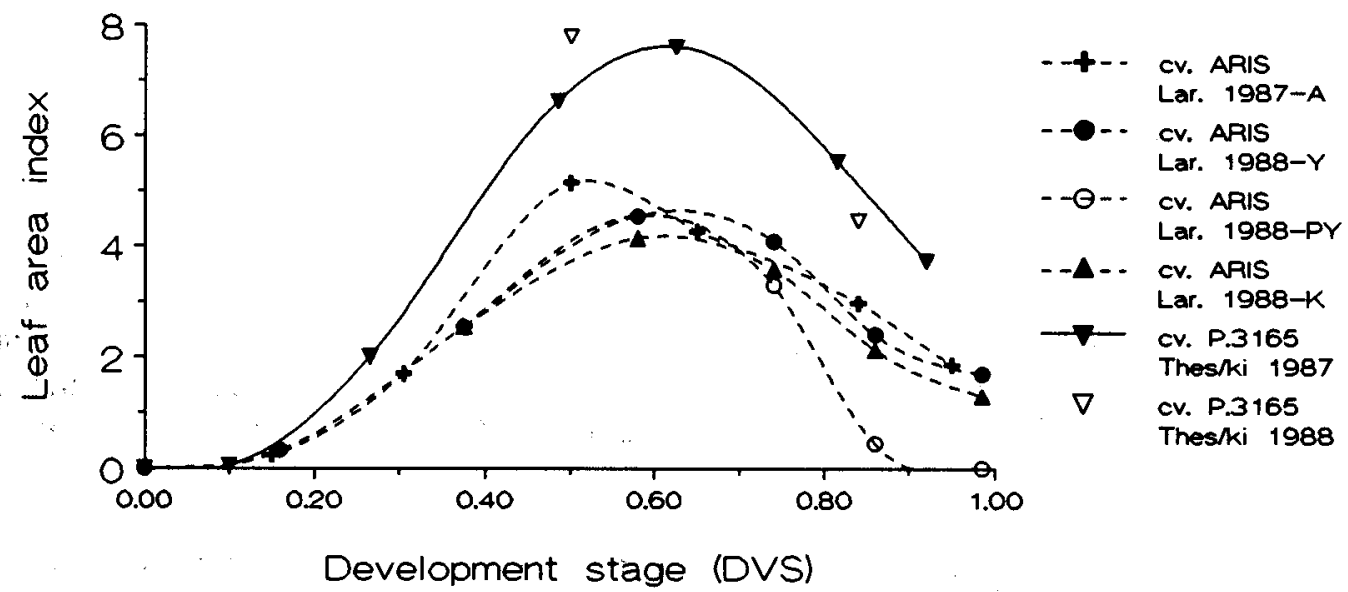

Fig 3. The LAl as a function of the development stage in various maize experiments with cr Aris and P3165-Dona (for details on the treatments see text).

There is no strict correlation between the LAl and the dry matter production unless it concerns crops growing under similar (weather) conditions. Maize cv P3165, for example, has a longer growing cycle and normally a higher LAl than cv Aris. It actually produced a higher dry seed yield in 1987 (13.4 vs $9.9 \mathrm{t} / \mathrm{ha}$ for P3165 and Aris, respectively), under optimum moisture conditions, but not in the dry year 1988 (9.7 and 11.5 t/ha for P3165 and
Aris, respectively), even though P3165 still had a higher LAl (fig 3). Cv Aris grown in Larissa in $1987\left(8.5 \mathrm{pl} / \mathrm{m}^{2}\right)$, had a higher LAl than on the same field in $1988\left(7 \mathrm{pl} / \mathrm{m}^{2}\right)$ and yet the final dry seed yield in 1987 was less than in 1988.

Figures 4, 5 and 6 show that the overall SLA of maize decreases in the course of the growing period. Sibma (1987) studied the SLA of maize plants at different altitudes and found that both 


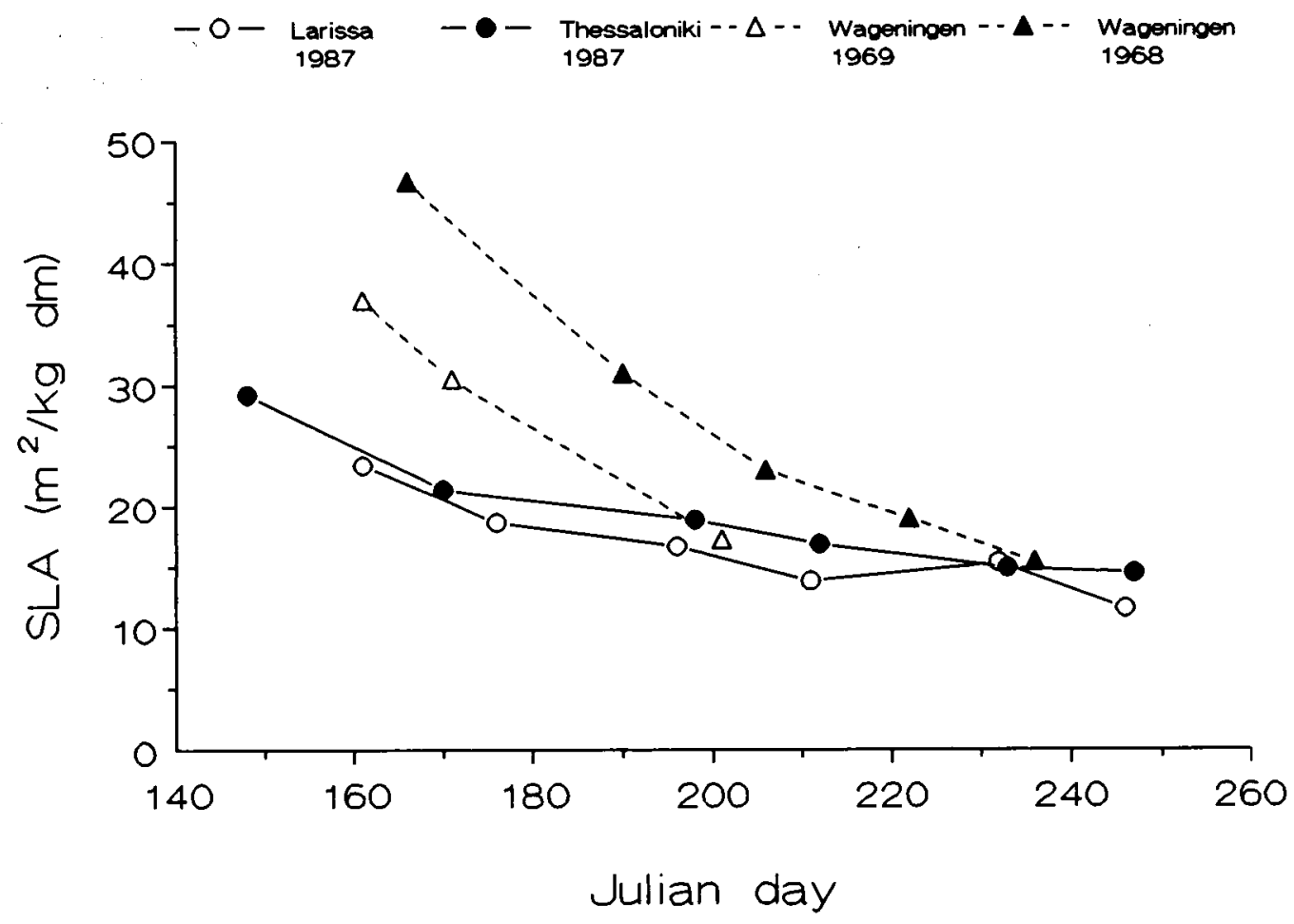

Fig 4. Change of the SLA of maize with time (data for Wageningen adapted from Sibma (1987)).

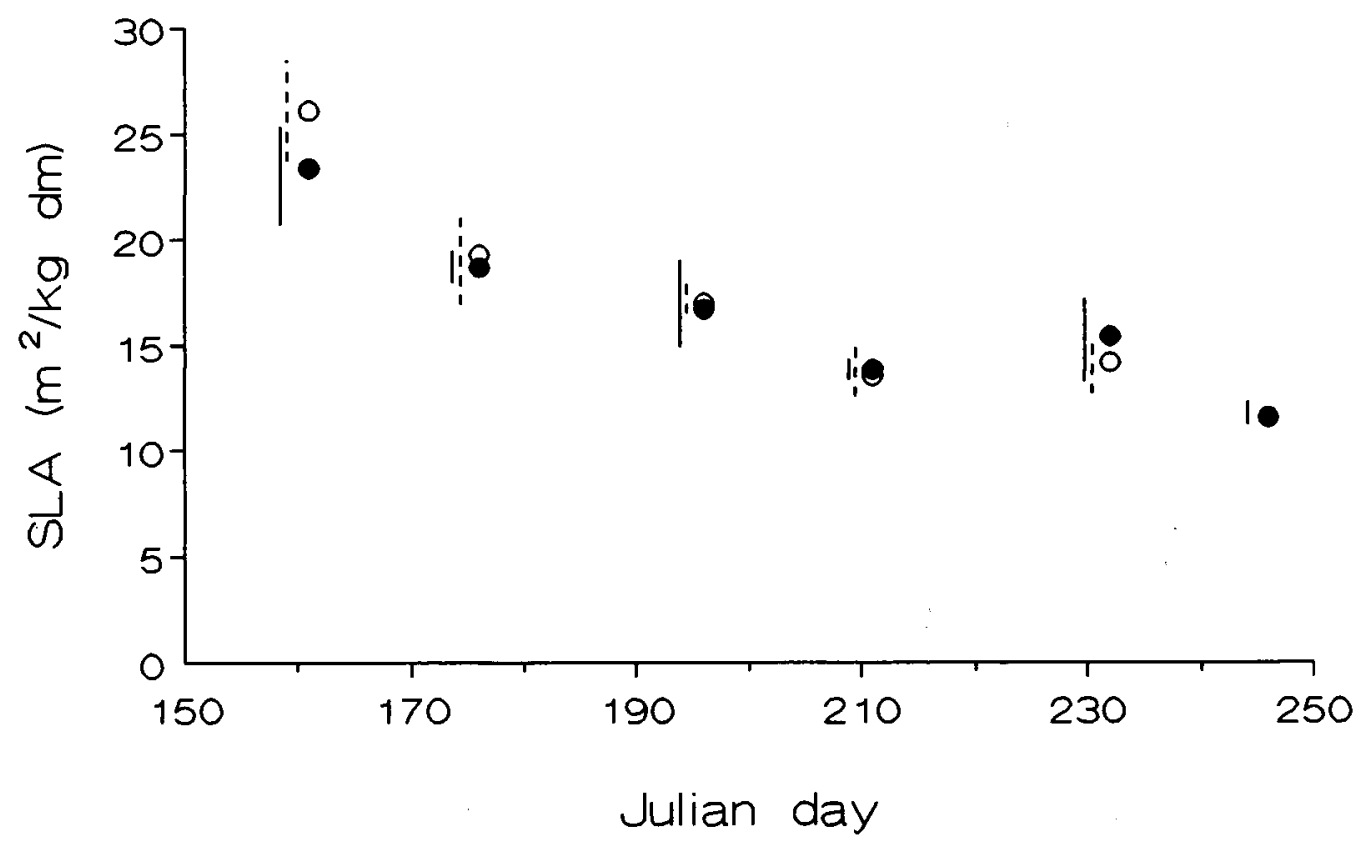

Fig 5. The specific leaf area (SLA, in $\mathrm{m}^{2} / \mathrm{kg} \mathrm{dm}$ ) of maize $\mathrm{cv}$ Aris at different plant densities $\left(4.5(0)\right.$ and $\left.8.5(\bullet) \mathrm{pl} / \mathrm{m}^{2}\right)$ in $\mathrm{Larissa}$, 1987 (vertical lines represent existing variation, dashed lines for the low plant density and full lines for the high density).

thickening of the existing leaves and formation of thicker new leaves account for this effect. Average SLA values under Greek (Mediterranean) and Dutch (temperate) circumstances (Sibma, 1987) are plotted for different years in figure 4. It appears that the initial SLA values under the Greek conditions are by $10-20 \mathrm{~m}^{2} / \mathrm{kg}$ dry matter less than the values found in the Netherlands. This might be associated with the higher light intensities prevailing under Mediterranean rather than temperate conditions at the beginning of the growing season. 
In figure 5, the overall SLA-values of maize $\mathrm{cv}$ Aris over time is shown for 2 plant densities of 4.5 and $8.5 \mathrm{pl} / \mathrm{m}^{2}$. No interaction was found between the SLA-DVS relationship and the plant density for the studied (normal) population range. Sibma (1987) only found an interaction for extreme plant densities, viz $40 \mathrm{pl} / \mathrm{m}^{2}$, with increased mutual shading, especially during late development stages.

In figure 6, the overall (average) SLA of the crop is plotted versus DVS values, calculated for the experiments in Larissa and Thessaloniki. The figure shows that SLA is highly correlated with DVS independent of the cultivar, soil, location and plant density. SLA can be approximated with the following logarithmic relationship:

$$
\begin{gathered}
\mathrm{SLA}=13.37-5.87 \ln (\mathrm{DVS}) \quad\left(\mathrm{m}^{2} / \mathrm{kg}\right) \\
R=0.94, n=34
\end{gathered}
$$

The correlation coefficient suggests that estimating DVS-values from the accumulated heat units, separately for the 2 periods emergenceflowering and flowering-maturity is accurate.

At the very early stages of the crop (April), the prevailing low radiation and temperatures around the threshold are responsible for the initial high values of SLA. In the period May to June, temperature (fig 1 ) and radiation increase sharply towards their optimum levels for crop-growth in the Mediterranean zone, resulting in very high photosynthetic rates and assimilate production. Assuming that translocation of the photosynthate products cannot fully match the increased rates of carbon fixation under the prevailing conditions, this results in the thickening of the existing leaves and the formation of thicker new leaves, and therefore in a sharp decrease of SLA in the preanthesis period. The post-anthesis period of corn coincides with the sunny and hot summer. During this period, not much difference in radiation and temperature may be expected in the Mediterranean region. Thus, the further slight decrease in SLA is attributed to the senescence of the old (thinner) leaves, so that the younger thicker leaves remain on the stand and determine the overall SLA-value. The SLA-DVS relationship, viz the sharp decrease of SLA in the initial stages of development to attain smaller rates later in the season, may be better described by a logarithmic-type model (equation [7]). It is believed that due to the considerably low year-toyear variation in summer radiation and temperature in the Mediterranean region, one might expect a high applicability of the proposed logarithmic equation [7] for maize grown under Mediterranean conditions (Driessen and Konijn, 1992).

cv. ARis

+ normal irrigation Larissa. 1988

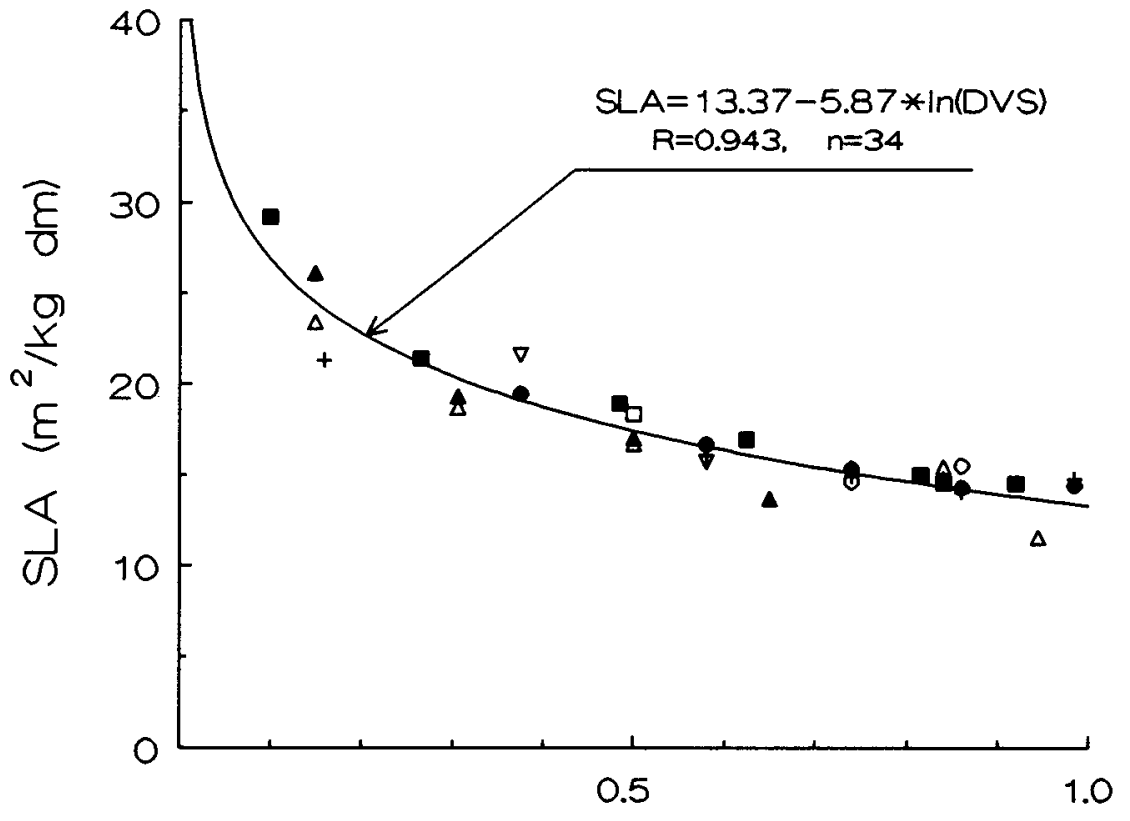

\section{Development stage (DVS)}

Fig 6. The SLA of maize at various development stages (DVS) in 1987 and 1988 (for details on the treatments see text). 


\section{Validation}

The validity of the empirical expression [7] was tested in the Agrinio area (western Greece) for 13 maize plantings during the growing period of 1991. The result is shown in figure $7 a$ and $b$ and illustrates a fairly good agreement between measured values (markers) and the (dashed) curve produced using equation [7]. This agreement is particularly good for early development stages, when maximum leaf growth takes place, and models simulating crop growth are very sensitive (sigmoid growth). As shown in figure 7 , the measured values at DVS $\leq 0.3$ are very
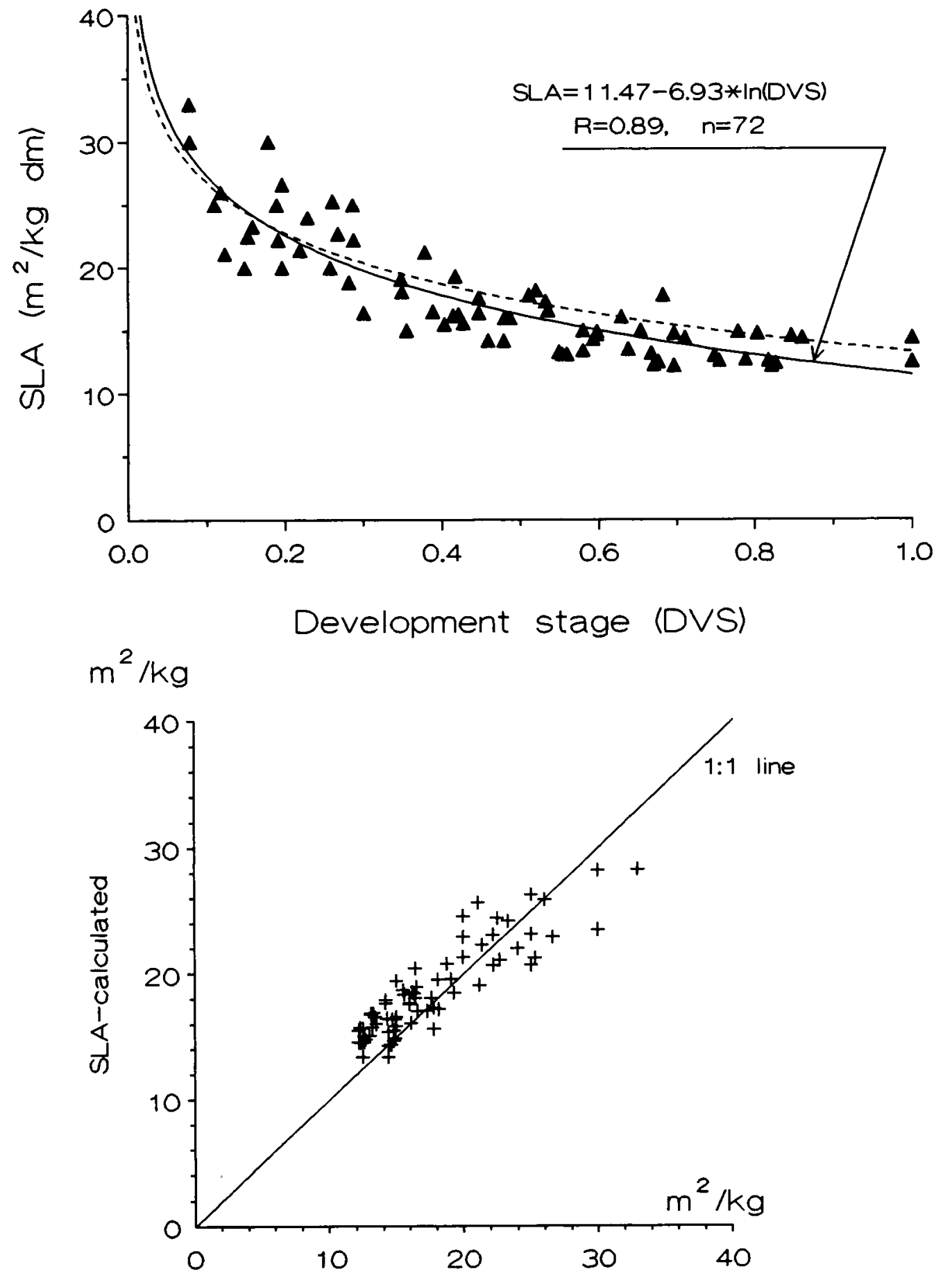

SLA-measured

Fig 7. a. Change of the SLA of maize with the development stage of 13 plantings in Agrinio, 1991 (markers). The dashed lines represents the empirical expression [7] (see text). b. Measured versus calculated (with equation [7]) SLA-values for the same plantings. 
slightly different (variation $\leq 2 \%$ ) from predicted values, whereas variation remains low until anthesis (DVS $\leq 0.5$ ). As figure 7 shows, however, the discrepancy increases in the postanthesis period (DVS $>0.5$ ) to reach a value of $10 \%$ at DVS $=0.75$ (middle of the grain-filling period). The lower SLA values in Agrinio during this period cannot be attributed either to lower temperatures (fig 1) or to higher radiation regimes, which was not the case. The noted discrepancy is probably due to the overestimation of the area index of no senescent (green) leaves by using the canopy analyzer rather than the more precise planometer measuring. In any case, any poor prediction of SLA in the postanthesis period cannot lead to erroneous results in dynamic simulations since no leaf development takes place during that period.

Based on the above, we suggest that in modern crop-growth models such as Sucros (Spitters et al, 1988), Wofost (Rappoldt, 1986), etc, the SLA-DVS relationships currently in use be replaced by equation [7] in dynamic simulations involving cultivars of Pioneer and possibly other single maize hybrids grown under Greek and more generally under Mediterranean conditions. For cultivars other than the ones studied here, a prerequisite calibration of the DVS-thermal time is needed.

\section{ACKNOWLEDGMENTS}

This work was partially financed by the Agricultural University of Wageningen, Dept of Soil Science and Geology and by the EC Project "Water and Solute Transport in European Soils - WASTES" (contract No. STEP-CT90-0032-C(DSCN)).

\section{REFERENCES}

Arnold CY (1975) Heat units systems in corn production. III Res 13, 6-7

Blacklow WM (1972) Influence of temperature on germination and elongation of the radicle and shoot of corn (Zea Mays L). Crop Sci 12, 647-650

Blackman GE, Black JN, Kemp AW (1955) Physiological and ecological studies in the analysis of plant environment. X. An analysis of the effects of seasonal variation in day light and temperature on the growth of Helianthus annuus in the vegetative phase. Ann Bot. 14, 527-548

Brower R, Kleinendorst A, Locher JT (1973) Growth responses of maize plants to temperature. In: Plant Response to Climatic Factors. Proc Upsala Symp 1970, UNESCO, Paris, France 169-174
Brown DM (1969) Heat Units for Corn in Southern Ontario. Can Dept of Agriculture and Food, AGDEX 111/31, ON, Canada

Butt AM (1968) Vegetative growth, morphogenesis and carbohydrate content of the onion plant as a function of light and temperature under field and controlled conditions. PhD Thesis, Agricultural University, Wageningen, The Netherlands

Chatterton NG, Lee DR, Hungerford WE (1972) Diurnal change in specific leaf weight of Medicago sativa L and Zea mays L. Crop Sci 12, 576-578

Coelho $D(1978)$ The consideration of temperature in corn (Zea mays $L$ ) growth and development models. PhD Thesis Purdue University, USA

Cooper CS (1966) Response of birdsfoot trefoil and alfalfa to various levels of shade. Crop Sci 6, 63-66

Danalatos NG (1993) Quantified analysis of selected land use systems in the Larissa region, Greece. PhD Thesis, Agricultural University of Wageningen, Wageningen, The Netherlands

Derieux M, Bonhomme R (1982) Heat unit requirements for maize hybrids in Europe. Results of the FAO Sub-Network I. Sowing-silking period. Maydica $27,59-77$

Driessen PM, Konijn NT (1992) Land-use Systems Analysis. Wageningen Agricultural University and INRES (Malang), Royal Library, The Hague, The Netherlands

Gilmore EC, Rogers JS (1958) Heat units as a method of measuring maturity in corn. Agron $J 50,611-615$

Gmeling Meyling HD (1973) Effect of light intensity and day length on the rate of leaf appearance in maize. Neth J Agric Sci 21, 68-76

Grobbelaar WP (1963) Responses of Young Maize Plants to Root temperatures. Agricultural University of Wageningen, The Netherlands 63(5)

Kleinendorst A, Brower R (1970) The effect of temperature of the root medium and of the growing point of the shoot on growth, water content and sugar content of maize leaves. Neth J Agric Sci 18, 140-148

Pears RB, Lee DR (1969) Photosynthetic and morphological adaptation of alfalfa leaves to light intensity at different stages of maturity. Crop Sci 9, 791794

Rappoldt C (1986) Crop Growth Simulation Model WOFOST. Documentation Version 3.0. Centre for World Food Studies, Wageningen, The Netherlands

Rench WE, Shaw RH (1971) Black layer development in corn. Agron J 63, 303-305

Sibma L (1987) Ontwikkeling en groei van (Zea mays) onder Nederlandse omstandigheden. Pudoc, Wageningen, The Netherlands

Spitters CJT, Van Keulen H, Van Kraailingen DWG (1988) A simple and universal crop growth simulation model, SUCROS 87. In: Simulation and Systems Management in Crop Protection ( $\mathrm{R}$ Rabbinge, $\mathrm{H}$ Van Laar, $\mathrm{S}$ Ward, eds) Simulation Monographs, PUDOC, Wageningen, The Netherlands, 147-181 
Tollenaar M, Daynard TM, Hunter RB (1979) Effect of temperature on rate of leaf appearance and flowering date in maize. Crop Sci 19, 363-366

Van Heemst HDJ (1986) Crop phenology and dry matter distribution. In: Modelling of Agricultural Production: Weather, Soils and Crops $(\mathrm{H}$ Van Keulen, J Wolf, eds) PUDOC, Wageningen, The Netherlands, 27-40
Van Heemst HDJ (1988) Plant Data Values Required for Simple Crop Growth Simulation Models: Review and Bibliography. Simulation Report CABO-TT 17, Wageningen, The Netherlands

Wolf J, Rijsdijk FH, Van Keulen H (1986) A Fortran model of crop production. In: Modelling of Agricultural Production: Weather, Soils and Crops (H Van Keulen, J Wolf, eds), Pudoc, Wageningen, The Netherlands, 343-384 